\title{
P-glycoprotein attenuates DNA repair activity in multidrug- resistant cells by acting through the Cbp-Csk-Src cascade
}

\author{
Li-Fang Lin ${ }^{1}$, Ming-Hsi Wu ${ }^{1}$, Vijaya Kumar Pidugu ${ }^{1,2}$, I-Ching Ho ${ }^{1}$, Tsann-Long Su ${ }^{1}$ \\ and Te-Chang Lee ${ }^{1,2,3}$ \\ ${ }^{1}$ Institute of Biomedical Sciences, Academia Sinica, Taipei 11529, Taiwan \\ ${ }^{2}$ Taiwan International Graduate Program in Molecular Medicine, National Yang-Ming University, Academia Sinica, Taipei \\ 11529, Taiwan \\ ${ }^{3}$ Institute of Pharmacology, National Yang-Ming University, Taipei 11221, Taiwan \\ Correspondence to: Te-Chang Lee, email: bmtcl@ibms.sinica.edu.tw
}

Keywords: P-glycoprotein, multidrug resistance, Cbp-Csk-Src cascade, DNA repair proteins

Received: October 07, $2016 \quad$ Accepted: January 24, 2017 Published: February 03, 2017

Copyright: Lin et al. This is an open-access article distributed under the terms of the Creative Commons Attribution License 3.0 (CC BY 3.0 ), which permits unrestricted use, distribution, and reproduction in any medium, provided the original author and source are credited.

\section{ABSTRACT}

Recent studies have demonstrated that P-glycoprotein (P-gp) expression impairs DNA interstrand cross-linking agent-induced DNA repair efficiency in multidrugresistant (MDR) cells. To date, the detailed molecular mechanisms underlying how P-gp interferes with Src activation and subsequent DNA repair activity remain unclear. In this study, we determined that the C-terminal Src kinase-binding protein ( $\mathrm{Cbp}$ ) signaling pathway involved in the negative control of Src activation is enhanced in MDR cells. We also demonstrated that cells that ectopically express $\mathbf{P}$-gp exhibit reduced activation of DNA damage response regulators, such as ATM, Chk2, Braca1 and Nbs1 and hence attenuated DNA double-strand break repair capacity and become more susceptible than vector control cells to DNA interstrand cross-linking (ICL) agents. Moreover, we demonstrated that P-gp can not only interact with $\mathrm{Cbp}$ and Src but also enhance the formation of inhibitory C-terminal Src kinase (Csk)-Cbp complexes that reduce phosphorylation of the Src activation residue Y416 and increase phosphorylation of the Src negative regulatory residue Y527. Notably, suppression of Cbp expression in MDR cells restores cisplatin-induced Src activation, improves DNA repair capacity, and increases resistance to ICL agents. Ectopic expression of Cbp attenuates cisplatin-induced Src activation and increases the susceptibility of cells to ICL agents. Together, the current results indicate that P-gp inhibits DNA repair activity by modulating Src activation via Cbp-Csk-Src cascade. These results suggest that DNA ICL agents are likely to have therapeutic potential against MDR cells with P-gp-overexpression.

\section{INTRODUCTION}

Multidrug resistance (MDR) is a significant obstacle to the success of chemotherapy in cancer patients [1]. Although MDR may be attributed to various mechanisms, it is often associated with increased expression of ATPbinding cassette $(\mathrm{ABC})$ transporter family members, which extrude anticancer drugs out of cells $[2,3]$. The $M D R 1$ gene product, $\mathrm{P}$-glycoprotein (P-gp), is one of the most well-known $\mathrm{ABC}$ transporters. $\mathrm{ABC}$ transporters expel a broad range of bioactive chemicals [4], including various anticancer drugs, such as vinblastine, vincristine, doxorubicin and paclitaxel $[5,6]$. Thus, overexpression of P-gp in tumor tissues is a prognostic indicator associated with poor response to chemotherapy and poor clinical outcome [7-9]. Numerous agents have been identified or developed to modify, modulate, or reverse the P-gpmediated MDR phenotype [1, 10, 11]. However, most of those agents were terminated during clinical trials because of their toxicities or unexpected outcomes [12]. Therefore, developing novel agents against P-gp and targeting alternative mechanisms that sensitize MDR cells to therapeutic agents may represent new paths toward overcoming MDR [11, 13]. 
Alternatively, numerous studies have shown that cancer cells with acquired MDR or ectopically expressed P-gp have increased sensitivity to DNA-damaging agents, including cisplatin $[14,15]$. Our previous study has also found that P-gp overexpression attenuates DNA repair in MDR cells damaged by DNA interstrand cross-linking (ICL) agents [16]. However, studies investigating how P-gp interferes with DNA repair are limited. We have previously revealed that Src activation by DNA-damaging agents is significantly reduced by $\mathrm{P}$-gp overexpression in MDR cells [16]. Because Src signaling plays crucial roles in the regulation of the DNA damage response (DDR) [17], our study suggests that P-gp interferes with Src activation.

Src, the first identified oncogene encoding a non-receptor tyrosine kinase, plays pivotal roles in coordinating diverse cellular responses involved in differentiation, adhesion and migration [18]. Src is overexpressed and activated in various human cancers [19], suggesting its role in tumor progression. Src also participates in controlling several parameters of cancer metastasis [20] and drug resistance [21, 22]. Several reports have identified associations between Src and resistance to irradiation, cisplatin, and paclitaxel $[17,23,24]$. Src activation-induced drug resistance is likely because of the activation of DNA-PK and enhancement of DNA double-strand break repair [25-27]. In addition, Src causes the dissociation of cyclindependent kinase 2 from cyclin A and induces S-phase arrest, thereby enhancing the repair of etoposide-induced DNA damage [28]. Therefore, targeting Src offers a novel therapeutic intervention strategy against cancer, particularly in the augmentation of chemosensitivity [29].

Oncogenic activation of Src requires phosphorylation at tyrosine $416\left(\mathrm{pSrc}^{\mathrm{Y} 416}\right)$ of the catalytic domain, whereas the enzymatic activity of Src is blocked when the tyrosine 527 of the C-terminal regulatory element is phosphorylated $\left(\mathrm{pSrc}^{\mathrm{Y} 527}\right)$ [30]. Phosphorylation of the C-terminal regulatory Y527 on Src is catalyzed by C-terminal Src kinase (Csk), a unique regulatory tyrosine kinase of the Src family [31]. Src is anchored to specific lipid-raft membrane domains via N-termini, whereas Csk, a cytoplasmic protein, is recruited via adaptor proteins to the membrane and inhibits Src [32]. Among several Csk-binding proteins [33-35], Csk-binding protein (Cbp), also known as phosphoprotein associated with glycosphingolipid-enriched membrane, is exclusively localized to lipid rafts and recruits Csk to efficiently inactivate Src $[36,37]$. Therefore, Cbp is known as a transmembrane adaptor protein of Csk. Previous studies have proposed that $\mathrm{Cbp}$ acts as a suppressor of Srcmediated cell migration [38], tissue repair [39], and tumor progression [40]. A recent study has also shown that P-gp plays a special role in Cbp recruitment [41]. Accordingly, we hypothesized that $\mathrm{Cbp}$ is a critical component involved in the P-gp-mediated regulation of Src in DNA-damaging agent-induced DNA repair. In this study, we conducted experiments to investigate whether P-gp mediates CbpCsk-dependent signaling to attenuate Src activation, thereby reducing DNA repair activity in MDR cells.

\section{RESULTS}

\section{Ectopic expression of P-glycoprotein inhibits cisplatin-induced activation of Src at Y416}

While we previously demonstrated that DNA damage significantly induces Src activation in parental $\mathrm{KB}$ cells but not in P-gp-overexpressing KBvin10 cells [16], we first confirmed that KBvin10 cells were more susceptible than KB cells to DNA cross-linking agents, such as cisplatin and BO-1922, a synthesized DNA ICL derivative of indolizino[6,7-b]indole (compound 18a in our previous report) [42] (Figure 1A). The $\mathrm{IC}_{50}$ values of KB cells to cisplatin and BO-1922 were 3.0 and 1.6 folds higher than those of KBvin10 cells, respectively. We further observed that cisplatin treatment markedly enhanced activated $\mathrm{Src}\left(\mathrm{pSrc}^{\mathrm{Y} 416}\right)$ but significantly reduced inactivated $\mathrm{Src}\left(\mathrm{pSrc}^{\mathrm{Y} 527}\right)$ in $\mathrm{KB}$ cells (Figure $\left.1 \mathrm{~B}\right)$. On the contrary, $\mathrm{pSrc}^{\mathrm{Y} 527}$ was enhanced whereas $\mathrm{pSrc}^{\mathrm{Y} 416}$ remained at a relatively low level in cisplatin-treated KBvin10 cells (Figure 1B). Moreover, we observed significantly increased EGFR phosphorylation at residue $\mathrm{Y}^{845}\left(\mathrm{pEGFR}^{\mathrm{Y} 845}\right)$, known as Src kinase specific phosphorylation site [43], in KB cells but not in KBvin 10 cells treated with cisplatin (Figure 1B). Total EGFR expression was not changed in either $\mathrm{KB}$ or KBvin10 cells after cisplatin treatment (Figure 1B), implying that Src activation in cisplatin treated KBvin 10 cells was attenuated by overexpressed P-gp.

MDR cells are generally established by long-term drug selection [44]. To further understand how P-gp attenuates DNA-damaging agent-induced Src activation, we ectopically expressed P-gp in Paca-S1 cells and established stable clones (Paca-S1-P1 and Paca-S1-P7) by culturing them in the medium containing vincristine. Because Paca-S1-P1 cells express higher levels of P-gp than Paca-S1-P7 cells (Figure 2A), they were chosen for this study. We first assessed the acquired resistance of Paca-S1-P1 cells to MDR drugs, such as vincristine, vinblastine, doxorubicin, etoposide, and paclitaxel. As summarized in Table 1, Paca-S1-P1 cells were crossresistant to all of these MDR drugs. However, Paca-S1-P1 cells were more susceptible than Paca-S1-V cells to DNA cross-linking agents, such as cisplatin, melphalan, carboplatin, and BO-1922. These results were consistent to our previous findings [16]. Furthermore, we showed that treatment of Paca-S1-V cells with $50 \mu \mathrm{M}$ cisplatin for $1 \mathrm{~h}$ and followed by incubation in drug-free medium resulted in increased $\mathrm{pSrc}^{\mathrm{Y} 416}$ but decreased $\mathrm{pSrc}^{\mathrm{Y} 527}$ in a time-dependent manner (Figure 2B). The relative intensity of $\mathrm{pSrc}^{\mathrm{Y} 416}$ and $\mathrm{pSrc}^{\mathrm{Y} 527}$ at $8 \mathrm{~h}$ was $1.85 \pm 0.03(n=3)$ and $0.66 \pm 0.01(n=3)$ in Paca-S1-V cells, respectively. However, no notable change was observed in Paca- 
Table 1: The $\mathrm{IC}_{50}$ values of various drugs against Paca-S1-V and P-gp-overexpressing Paca-S1-P1 cells $^{\mathrm{a}}$

\begin{tabular}{lccc}
\hline \multicolumn{1}{c}{ Drugs } & Paca-S1-V & Paca-S1-P1 & RF $^{\mathrm{b}}$ \\
\hline Vincristine $(\mathrm{nM})$ & $3.4 \pm 1.2$ & $37,270 \pm 317$ & 10,961 \\
Vinblastine $(\mathrm{nM})$ & $1.6 \pm 0.0$ & $317.2 \pm 4.5$ & 198 \\
Doxorubicin $(\mathrm{nM})$ & $20.2 \pm 6.5$ & $1,389 \pm 30.1$ & 69 \\
Etoposide $(\mu \mathrm{M})$ & $2.9 \pm 0.3$ & $35.4 \pm 4.3$ & 12 \\
Paclitaxel $(\mu \mathrm{M})$ & $0.03 \pm 0.00$ & $2.0 \pm 0.2$ & 67 \\
Cisplatin $(\mu \mathrm{M})$ & $19.6 \pm 0.4$ & $12.6 \pm 2.8$ & 0.64 \\
Carboplatin $(\mu \mathrm{M})$ & $56.1 \pm 1.8$ & $51.4 \pm 0.5$ & 0.91 \\
Melphalan $(\mu \mathrm{M})$ & $109.6 \pm 4.0$ & $66.5 \pm 5.4$ & 0.61 \\
BO-1922 $(\mu \mathrm{M})$ & $0.52 \pm 0.02$ & $0.26 \pm 0.08$ & 0.50 \\
\hline
\end{tabular}

${ }^{\mathrm{a}} \mathrm{IC}_{50}$ values are the drug concentrations that inhibit cell growth by $50 \%$. The data are expressed as means $\pm \mathrm{SE}$ of three independent experiments.

${ }^{\mathrm{b}} \mathrm{RF}$, resistant factor $\left(\mathrm{IC}_{50}\right.$ of Paca-S1-P1 cells/ $/ \mathrm{IC}_{50}$ of Paca-S1-V cells).
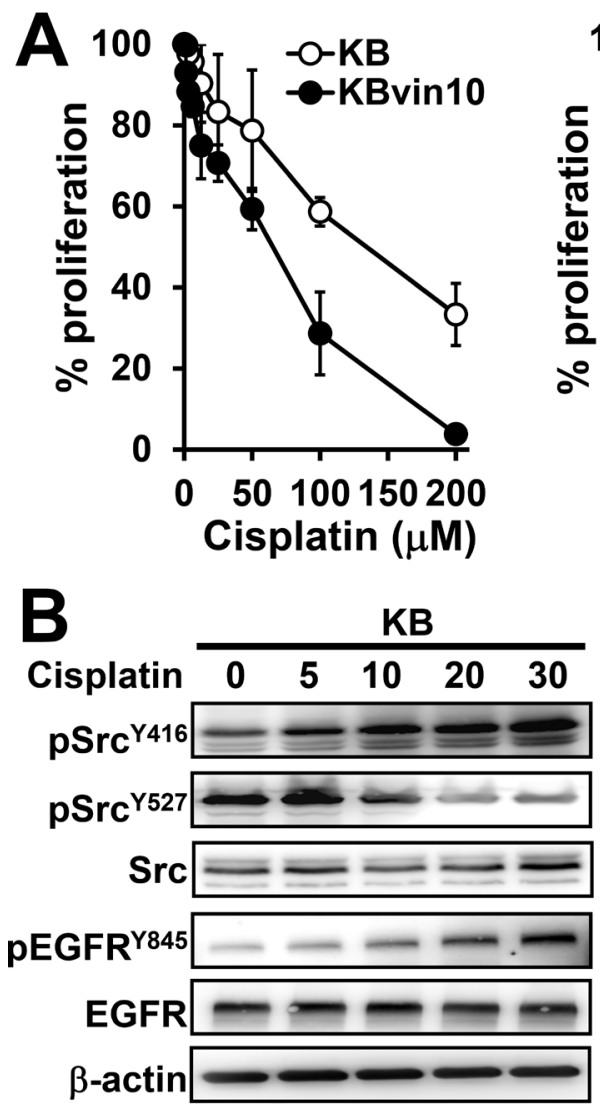
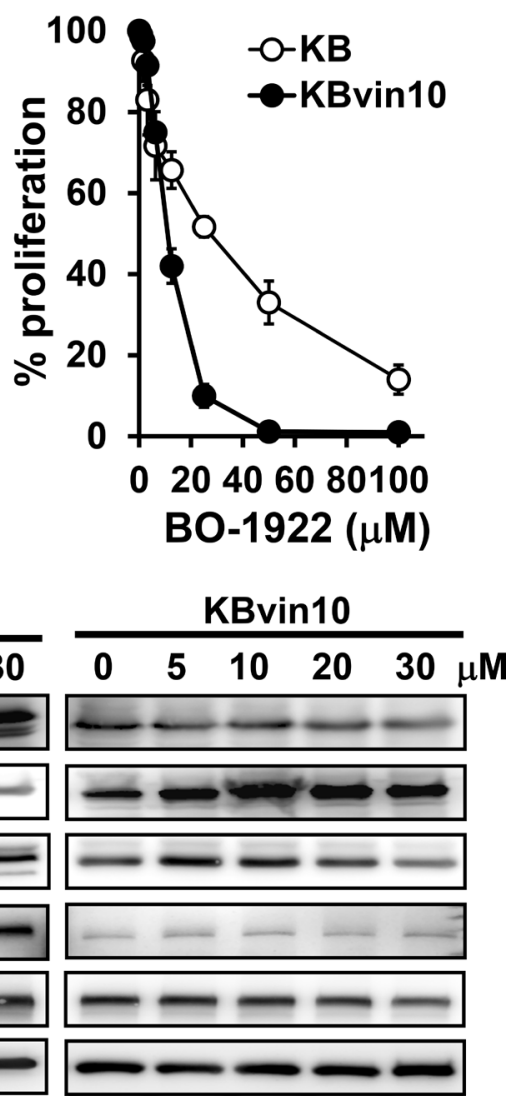

Figure 1: Increased susceptibility to DNA damaging agents and decreased Src activation in P-gp overexpressed KBvin10 cells. (A) Increasing cytotoxic effects of DNA damaging agents to KBvin10 cells. KB and KBvin10 cells were treated with various concentrations of cisplatin or BO-1922 for $1 \mathrm{~h}$, washed with phosphate buffered saline (PBS) and then incubated with fresh medium for $72 \mathrm{~h}$. The cell proliferation was analyzed using Presto-Blue. Bars are SD of three independent experiments. (B) No significant Src activation in KBvin 10 cells treated with cisplatin. KB or KBvin 10 cells were treated with various concentrations of cisplatin for $1 \mathrm{~h}$, washed with PBS, and incubated with fresh medium for $2 \mathrm{~h}$. The levels of $\mathrm{Src} \mathrm{pSrc}^{\mathrm{Y} 416}$ (active) and $\mathrm{pSrc}^{\mathrm{Y} 527}$ (inactive), EGFR and $\mathrm{pEGFR}^{\mathrm{Y} 845}$ were $^{2}$ determined by western blotting. $\beta$-actin was included as a loading control. 
S1-P1 cells treated with cisplatin. We further confirmed these findings by treatment of Paca-S1-V cells or PacaS1-P1 cells with various concentrations of cisplatin for $4 \mathrm{~h}$. As shown in Figure 2C, activated $\mathrm{pSrc}^{\mathrm{Y} 416}$ was increased whereas inactivated $\mathrm{pSrc}^{\mathrm{Y} 527}$ decreased in a dose-dependent manner in Paca-S1-V cells but not in Paca-S1-P1 cells. The relative intensity of $\mathrm{pSrc}^{\mathrm{Y} 416}$ and $\mathrm{pSrc}^{\mathrm{Y} 527}$ at $100 \mu \mathrm{M}$ to control was $2.27 \pm 0.04(n=4)$ and $0.53 \pm 0.04(n=4)$ in Paca-S1-V cells, respectively. However, there was no change in Paca-S1-P1 cells. In addition, we also observed that cisplatin treatment resulted in dose-dependent increase of $\mathrm{pEGFR}^{\mathrm{Y} 845}$ in Paca-S1-V cells but dose-dependent decrease in PacaS1-P cells. Since KBvin10 and Paca-S1-P1 cells were acquired by selection in medium containing vincristine, we performed similar experiments using KB cells that were transiently expressed P-gp without drug selection. As shown in Supplementary Figure 1, similar results were observed, suggesting that P-gp indeed played certain role on attenuating the Src activation. These results similar to those observed in KBvin10 cells further implicated that P-gp may contribute to the resistance of MDR drugs by attenuation of DNA damaging agent induced Src activation.

\section{Ectopic expression of P-glycoprotein suppresses DNA damage response}

Since we have shown increased susceptibility to DNA crosslinking agents in P-gp overexpressing cells, we then adopted phosphorylated histone $\mathrm{H} 2 \mathrm{AX}(\gamma \mathrm{H} 2 \mathrm{AX})$ as DNA damage marker to further confirm the interference

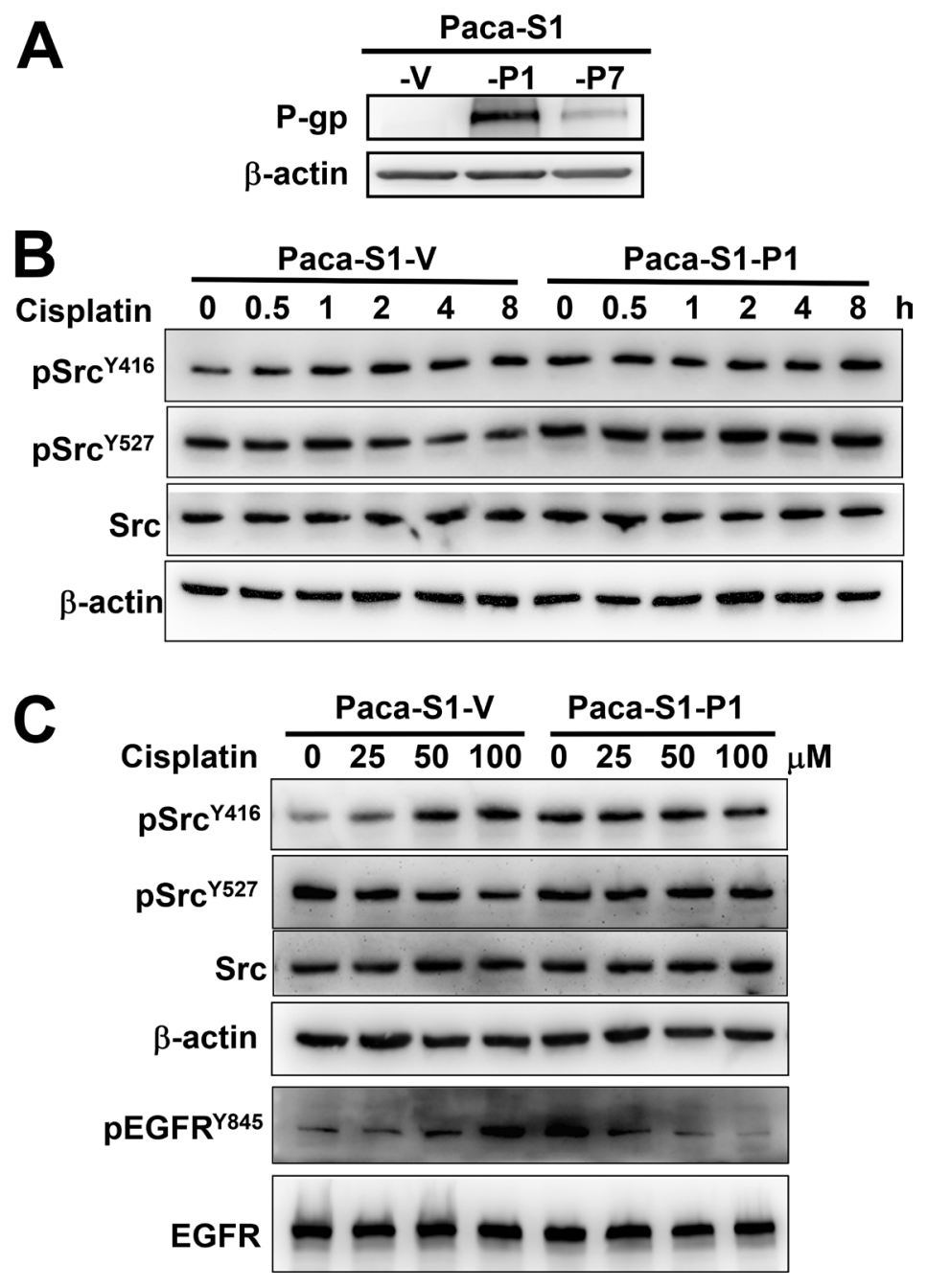

Figure 2: Attenuation of cisplatin-induced Src activation in P-gp overexpressing Paca-S1 cells. (A) Enhanced expression of P-gp in Paca-S1 cells transfected with a P-gp-expressing vector. Two stable P-gp expressing cell lines, Paca-S1-P1 and -P7, were established and maintained in medium containing $10 \mathrm{nM}$ vincristine. Paca-S1-V cells were transfected with expression vector and served as a control. The protein levels of P-gp were analyzed by western blotting. (B and $\mathbf{C}$ ) Time- and dose-dependent modulation of pSrc ${ }^{\mathrm{Y} 416}$ and $\mathrm{pSrc}^{\mathrm{Y} 527}$ in Paca-S1-V and -P1 cells, respectively. As described in Figure 1, Paca-S1-V and Paca-S1-P1 cells were treated either with $50 \mu \mathrm{M}$ cisplatin for $1 \mathrm{~h}$, washed, and incubated in the fresh medium for various time periods as indicated (B) or various concentrations for $1 \mathrm{~h}$, washed, and incubated for $4 \mathrm{~h}(\mathrm{C})$. The protein levels of total Src, $\mathrm{pSrc}^{\mathrm{Y} 416}, \mathrm{pSrc}^{\mathrm{Y} 527}$, EGFR, and pEGFR ${ }^{\mathrm{Y} 845}$ were analyzed by western blotting. 
of DNA repair in P-gp overexpressing cells. As shown in Figure $3 \mathrm{~A}, \gamma \mathrm{H} 2 \mathrm{AX}$ was significantly increased at $24 \mathrm{~h}$ and gradually declined at 48 and $72 \mathrm{~h}$ in Paca-S1-V, indicating that the damaged DNA was gradually repaired. However, the levels of $\gamma \mathrm{H} 2 \mathrm{AX}$ were constantly maintained in Paca$\mathrm{S} 1-\mathrm{P} 1$ cells up to $72 \mathrm{~h}$, implying no significant DNA repair in Paca-S1-P1 cells. Similar results were observed in PacaS1-V and Paca-S1-P1 cells treated with BO-1922, which is a potent agent to induce DNA interstrand crosslinks [42] (Supplementary Figure 2). These results implicated that attenuated Src activation by overexpressed P-gp may interfere with DDR. As shown in Figure 3B, we did not observed the change of protein levels of several proteins involved in DDR, such as ATM, Chk2, Brca1, Nbs1, Mre11, $\operatorname{Rad} 50, \operatorname{Rad} 51$, and FANCD2, in cisplatin treated cells either with P-gp overexpression (Paca-S1-P1 and KBvin 10 cells) or without (Paca-S1-V cells and KB cells). However, we found that in response to cisplatin treatment the phosphorylated ATM (pATM $\left.{ }^{\mathrm{S} 1981}\right), \mathrm{Chk} 2\left(\mathrm{pChk} 2^{\mathrm{T} 68}\right)$, Brcal ( $\left.\mathrm{pBrca}^{\mathrm{S} 1524}\right)$, and $\mathrm{Nbs} 1\left(\mathrm{pNbs}^{\mathrm{S} 343}\right)$ were increased in a time-dependent manner in Paca-S1-V cells and KB cells, respectively. In cisplatin-treated Paca-S1-P1 and KBvin10 cells, the levels of phosphorylation of these proteins were apparently less than that in Paca-S1-V cells and KB cells, respectively. These results supported that $\mathrm{P}$-gp attenuated Src activation and subsequently prevented the activation of DDR signaling in cells treated with DNA damaging agents. Consequently, P-gp overexpressing cells were more susceptible to DNA cross-linking agents compared to their parental cells.

\section{P-glycoprotein interacts with Src, Cbp, and Csk}

Src is negatively regulated by Csk, which phosphorylates Src at Y527 [45]. While Csk was recruited to the membrane by the Src suppressor Cbp [40], P-gp

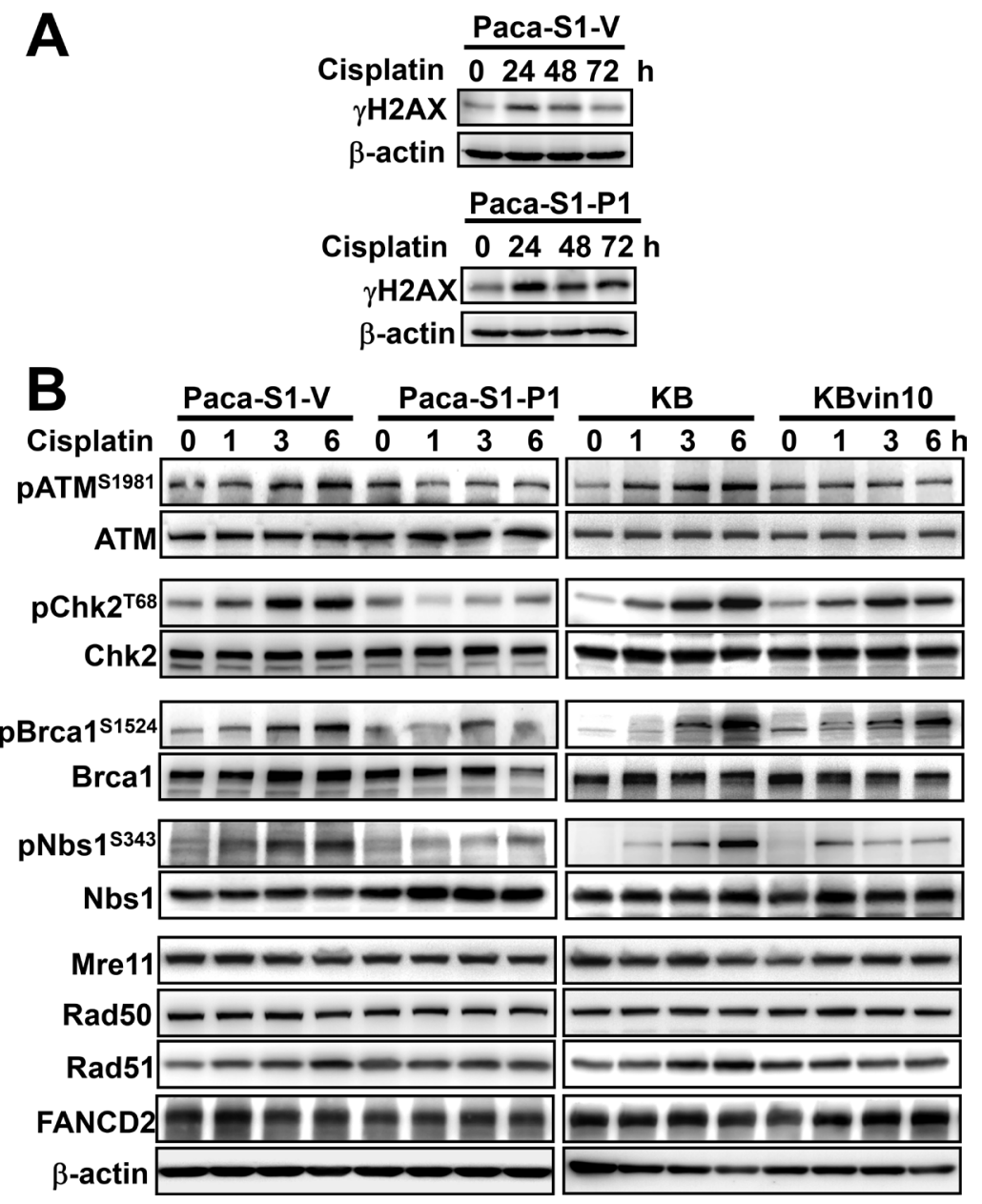

Figure 3: Reduced DNA damage response in cisplatin-treated P-gp overexpressing cells. (A) Accumulated gH $2 \mathrm{AX}$ in Paca-S1-P1 cells treated with cisplatin. Paca-S1-V and Paca-S1-P1 cells were treated with $50 \mu \mathrm{M}$ cisplatin for $1 \mathrm{~h}$, washed and cultured in drug-free medium for various time periods. The protein levels of $\gamma \mathrm{H} 2 \mathrm{AX}$ were determined by western blotting. (B) Attenuation of DNA repair protein activation by P-gp. Paca-S1-V and Paca-S1-P1 cells were treated with $50 \mu \mathrm{M}$ cisplatin and KB and KBvin10 cells with $20 \mu \mathrm{M}$ cisplatin for $1 \mathrm{~h}$, washed, and incubated for $0,1,3$ and $6 \mathrm{~h}$. Afterward, several DDR related proteins with or without activated phosphorylation, such as ATM and pATM ${ }^{\mathrm{s} 1981}$, Chk2 and pChk2 $2^{\mathrm{T} 68}$, Brca1 and pBrca $1^{\mathrm{S} 1524}$, Nbs1 and pNbs1 ${ }^{\mathrm{S} 343}$, and total proteins of Mre11, Rad50, Rad51, and FANCD2 were analyzed by western blotting. $\beta$-actin was included as a loading control. 
was reported to recruit $\mathrm{Cbp}$ to the membrane [41]. We therefore investigated the role of Csk and Cbp in P-gp resulted in suppression of DNA damage induced Src activation. We first observed that P-gp overexpression did not affect Csk protein levels (Figure 4A). However, Cbp protein levels (Figure 4A) and mRNA levels (Figure 4B) were significantly enhanced in KBvin 10 and Paca-S1-P1 cells compared to their parental KB and Paca-S1-V cells, respectively. We further observed a slow degradation of $\mathrm{Cbp}$ in KBvin 10 cells compared with $\mathrm{KB}$ cells after treatment with cycloheximide (CHX) (Figure 4C). The estimated half-life of $\mathrm{Cbp}$ in $\mathrm{KB}$ cells was approximately $2 \mathrm{~h}$, whereas no apparent Cbp degradation was observed in KBvin 10 cells within $4 \mathrm{~h}$. These results implied that P-gp not only enhances the expression of $\mathrm{Cbp}$ but also prolongs the stability of $\mathrm{Cbp}$.
To explore the underlying mechanism through which P-gp attenuates Src activation, we examined the interaction between P-gp, Src, and $\mathrm{Cbp}$ by reciprocal immunoprecipitation assays using antibodies against P-gp, Src, and Cbp, respectively. As shown in Figure 5A, we confirmed the interaction between Src and Cbp. However, using antibody against one of these proteins, we observed that the other 2 proteins were co-precipiated in lysates of KBvin 10 cells. These results revealed a direct interaction between $\mathrm{P}$-gp, $\mathrm{Cbp}$ and $\mathrm{Src}$ in $\mathrm{P}$-gp overexpressing KBvin10 The co-localization of P-gp and Src as well as P-gp and Cbp on the plasma membrane was further confirmed by immunofluorescence analysis in KBvin 10 cells (Figure 5B). Similar results were found in Paca-S1 cells (Supplementary Figure 3). In addition, a large portion of Src and $\mathrm{Cbp}$ were localized in the cytosol. Intriguingly,
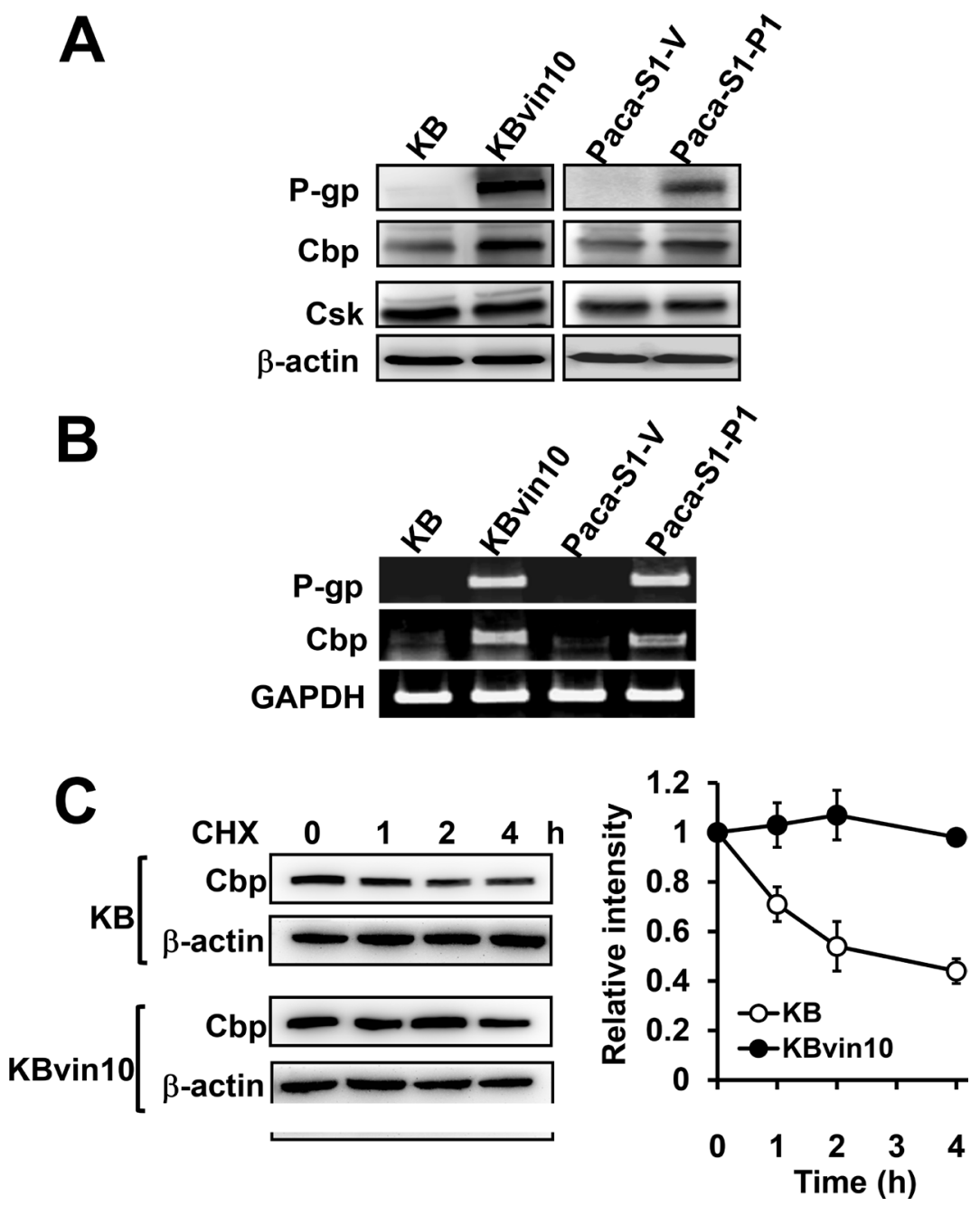

Figure 4: Increased Cbp expression and stability in P-gp overexpressing cells. (A and B) Increased Cbp protein (A) and mRNA (B) in P-gp-overexpressing cells. The protein levels of P-gp, Cbp and Csk and the mRNA levels of P-gp and Cbp in KB, KBvin10, Paca-S1-V and Paca-S1-P1 cells were analyzed by western blotting and RT-PCR, respectivley. $\beta$-actin was included as a loading control in western blotting assay, while GAPDH expression served as an internal control of RT-PCR assay. (C) Increased Cbp stability in P-gpoverexpressing KBvin 10 cells. KB and KBvin10 cells were incubated with cycloheximide (CHX) $(20 \mu \mathrm{g} / \mathrm{ml})$ for the indicated time periods. The protein levels of $\mathrm{Cbp}$ were determined by western blotting (left). $\beta$-actin was included as a loading control. The relative intensity of Cbp (right) was determined by imaging software. Bars are SD of three independent experiments. 
the interaction of P-gp and Csk was limited in KBvin10 cells without exposure to DNA-damaging agents but significantly increased upon cisplatin treatment (Figure 6). However, the interaction of Cbp and Csk was not affected by cisplatin treatment. Accordingly, we may infer that upon cisplatin treatment P-gp enhances the recruitment of Csk from the cytosol to the cell membrane, where Csk phosphorylates Src at Y527 and attenuates Src activation.

\section{P-glycoprotein and Cbp silencing restores} cisplatin-induced activation of Src at Y416 and DNA repair capacity in MDR cells

To further reveal the roles of P-gp and $\mathrm{Cbp}$ in the suppression of cisplatin-induced Src activation, we established P-gp- and Cbp silenced KBvin 10 cells by infecting the cells with P-gp or Cbp lentiviral shRNA, respectively. KBvin10-shLuc cells infected with lentiviral luciferase shRNA were used as a control. Reduced P-gp and Cbp protein levels in KBvin10-shP-gp and KBvin10-shCbp compared to KBvin10-shLuc cells was demonstrated by western blotting analysis (Figure 7A). We also confirmed increased resistance to cisplatin in P-gp or Cbp silenced KBvin10 cells (Figure 7B). As described above, we inferred that P-gp restrained Cbp turnover, resulting in its accumulation and hence suppression of DNA damage-induced Src activation. We further demonstrated that the DNA damage marker $\gamma \mathrm{H} 2 \mathrm{AX}$ accumulated in KBvin10-shLuc cells treated with cisplatin up to $48 \mathrm{~h}$ and then declined (Figure $7 \mathrm{C}$ ). However, no

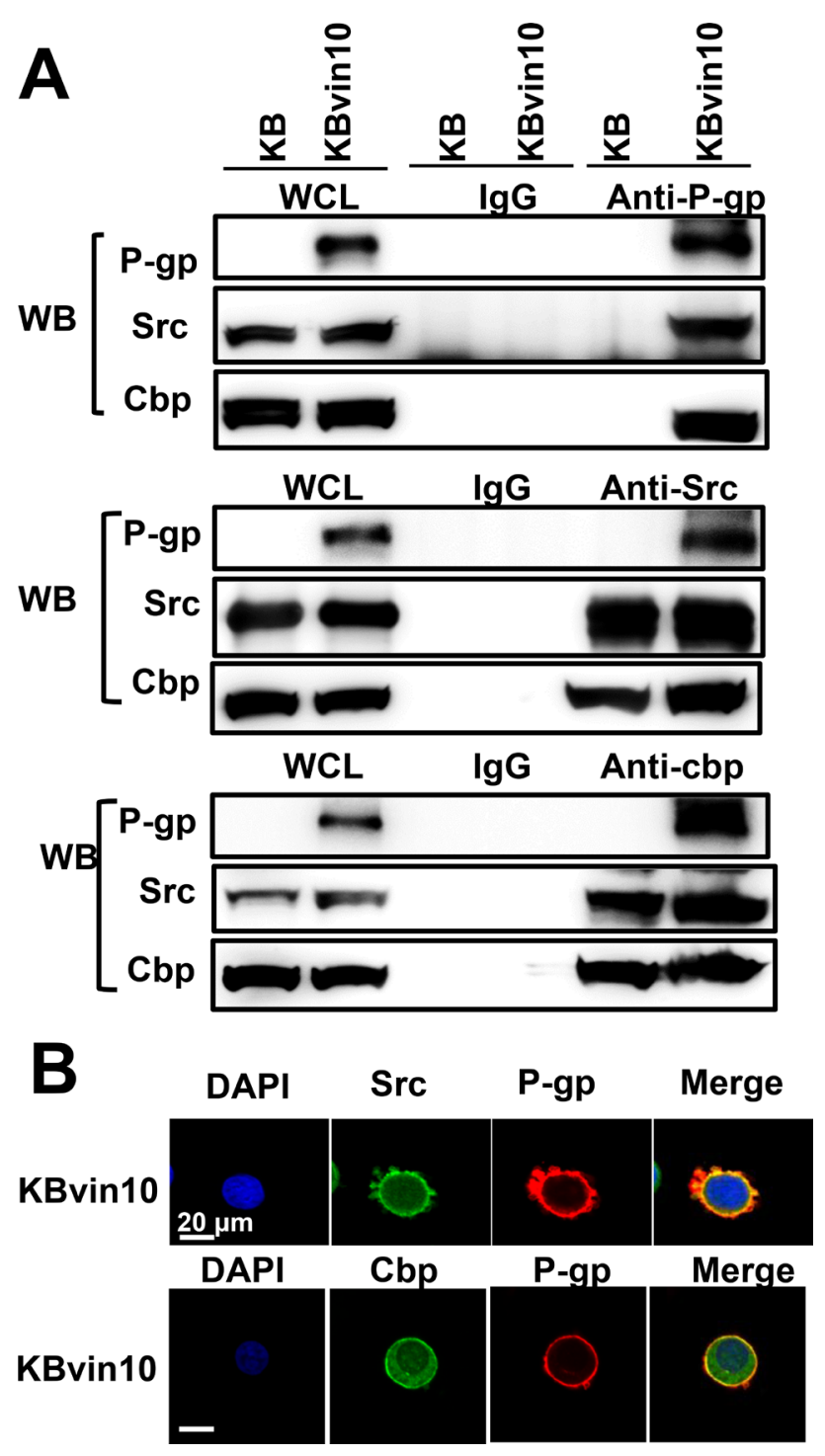

Figure 5: Interaction among P-gp, Src, and Cbp. (A) Co-immunoprecipitation of P-gp, Src, and Cbp. Cell lysates from KB and KBvin 10 cells were immunoprecipitated with antibodies against P-gp, Src or Cbp. The immuno-complexes were reciprocally subjected to western blotting using P-gp, Src, and Cbp antibodies, respectively. (B) Co-localization of P-gp, Src, and Cbp in KBvin10 cells. Logarithmically growing cells were fixed and stained with immunofluorescent antibodies as described in MATERIALS AND METHODS. The images were acquired by confocal microscopy. 
significant increase in $\gamma \mathrm{H} 2 \mathrm{AX}$ was observed in cisplatintreated KBvin10-shCbp cells (Figure 7C), implying that cisplatin-induced DNA damages were rapidly rescued and repaired in KBvin10-shCbp cells compared with KBvin10-shLuc cells. To confirm this finding, we adopted a modified comet assay to compare the repair activity of DNA ICLs in KBvin10-shLuc and KBvin10-shCbp cells. As shown in Figure 7D, Cbp silencing accelerated the repair of DNA ICLs.

Moreover, the effects of cisplatin treatment on Src activation in KBvin10-shLuc, KBvin10-shP-gp, and KBvin10-shCbp cells were examined by determining the levels of $\mathrm{pSrc}^{\mathrm{Y} 416}$ and $\mathrm{pSrc}^{\mathrm{Y} 527}$. Similar to the parental KBvin10 cells, no significant increase of $\mathrm{pSrc}^{\mathrm{Y} 416}$ was observed in the cisplatin-treated vector control KBvin10shLuc cells (Figure 8A). Alternatively, pSrc $^{\mathrm{Y} 527}$ was significantly increased in cisplatin-treated control KBvin10-shLuc (Figure 8A). However, activated pSrc ${ }^{\mathrm{Y} 416}$ was significantly increased by cisplatin in both KBvin10shP-gp cells (Figure 8B) and Cbp-silenced KBvin10shCbp cells (Figure 8C). Consistently, the protein levels of inactivated $\mathrm{pSrc}^{\mathrm{Y} 527}$ were reduced in cisplatin treated KBvin10-shP-gp cells (Figure 8B) and KBvin10-shCbp cells (Figure 8C). These results further support that P-gp and $\mathrm{Cbp}$ may serve as negative regulators of Src. Their overexpression in MDR cells was likely to sensitize the MDR cells to DNA cross-linking agents.

\section{Ectopic expression of $\mathrm{Cbp}$ inhibits cisplatin- induced activation of Src in KB cells}

To further verify the inhibitory role of Cbp in DNAdamaging agent-induced Src activation, we ectopically expressed $\mathrm{Cbp}$ in $\mathrm{KB}$ cells and established stable clones (KB-AcGFP-Cbp) (Figure 9A). We observed that KBAcGFP-Cbp cells were more susceptible to cisplatin than KB and control KB-AcGFP cells (Figure 9B). Furthermore, cisplatin treatment failed to induce $\mathrm{pSrc}^{\mathrm{Y} 416}$ but significantly increased $\mathrm{pSrc}^{\mathrm{Y} 527}$ in $\mathrm{KB}-\mathrm{AcGFP}-\mathrm{Cbp}$ cells (Figure 9C), supporting the inhibitory role of Cbp in cisplatin-induced Src activation. We further performed an in vivo assay to evaluate the therapeutic activity of cisplatin against KBvin10 cells with differential expression of Cbp. As shown in Figure 9D, the KBvin10shLuc and KBvin10-shCbp xenografts were treated in situ with normal saline or cisplatin at $4 \mathrm{mg} / \mathrm{kg}$. At day 10, cisplatin suppressed the growth of the KBvin10shLuc and KBvin 10 -shCbp xenografts by $80.5 \%$ and $41.1 \%$, respectively, suggesting that silencing of $\mathrm{Cbp}$ resulted in increased cisplatin resistance. Similarly, cisplatin treatment reduced the tumor growth of KB-GFP and KB-Cbp xenografts by $54.6 \%$ and $80.7 \%$, respectively (Figure 9E), confirming that enhanced expression of Cbp sensitizes the cells to cisplatin. Together, these results indicate that P-gp interacts with $\mathrm{Cbp}$ and Src to recruit Csk to attenuate Src activation upon DNA injury, a crucial signal for activation of the DNA repair machinery.

\section{DISCUSSION}

Although P-gp acts as an efflux pump responsible for preventing the delivery of various chemotherapeutic agents to cancer cells, several reports have demonstrated that increased P-gp levels enhance the sensitivity of MDR cancer cells to various DNA-damaging agents, such as cisplatin, bis-chloroethylnitrosourea, and gemcitabine
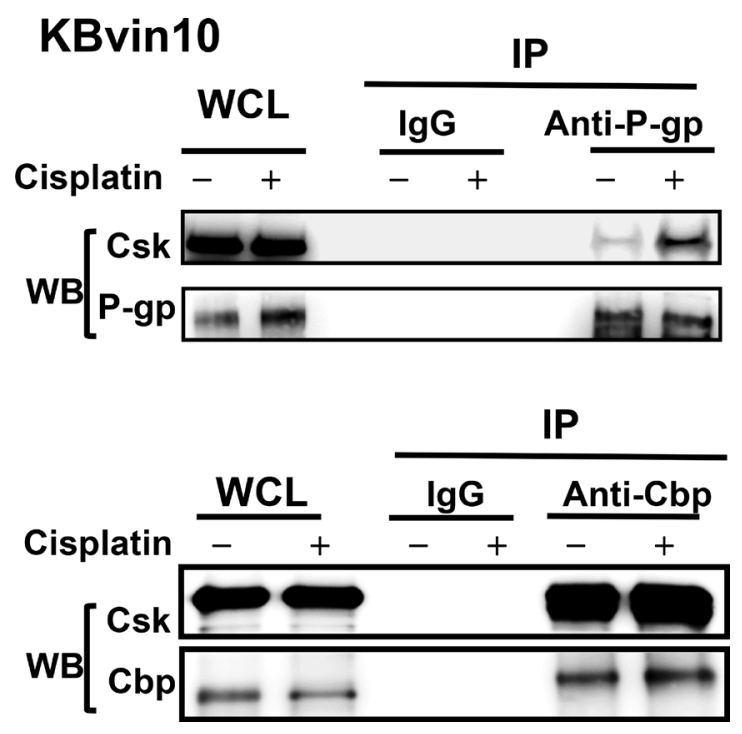

Figure 6: Association of P-gp with Csk in cisplatin-treated KBvin10 cells. KBvin10 cells were treated with or without cisplatin at $20 \mu \mathrm{M}$ for $1 \mathrm{~h}$, washed, and then incubated with fresh medium for $2 \mathrm{~h}$. Cell lysates were immunoprecipitated with antibodies against P-gp or Cbp and followed by western blotting with anti-P-gp, anti-Csk, or anti-Cbp antibodies, respectively. Normal mouse immunoglobulin (IgG) was included as a negative control and 1/10 of whole cell lysates (WCL) used for immunoprecipitation was included as loading control. 
$[14,15,46]$. Several possible explanations have been reported to account for the toxicity of P-gp-potentiated compounds, including generation of reactive oxygen species through ATP hydrolysis, altered drug metabolism, and membrane perturbation $[47,48]$. We have previously shown that overexpressed P-gp in MDR cells attenuates the Src-activated repair activity by DNA ICLs and contributes to the susceptibility of MDR cells to DNA ICL agents [16]. In this report, we revealed mechanistic insights regarding how $\mathrm{P}$-gp interferes with Src activation and DNA repair activity. Our results first demonstrated that the expression levels of P-gp were inversely associated with Src activation and repair of cisplatin-induced DNA ICLs. Second, we noticed that P-gp overexpression attenuated the DDR upon treatment with DNA damaging agents. Third, we observed significantly increased expression of $\mathrm{Cbp}$ in P-gp-overexpressing cells, in which P-gp interacts with $\mathrm{Cbp}$ and prolongs its stability. Fourth, upon cisplatin treatment, we revealed an interaction between P-gp and Csk in KBvin10 cells in which Cbp levels were enhanced. Fifth, the repair of cisplatin-induced ICLs and Src activation were suppressed by ectopically expressed Cbp, whereas Cbp silencing enhanced cisplatin-induced Src activation and increased the resistance of MDR cells to DNA ICL agents. Together, our present results revealed that overexpressed P-gp in MDR cells mediates through a Cbp-dependent mechanism to attenuate and Src activation and DNA repair activity.

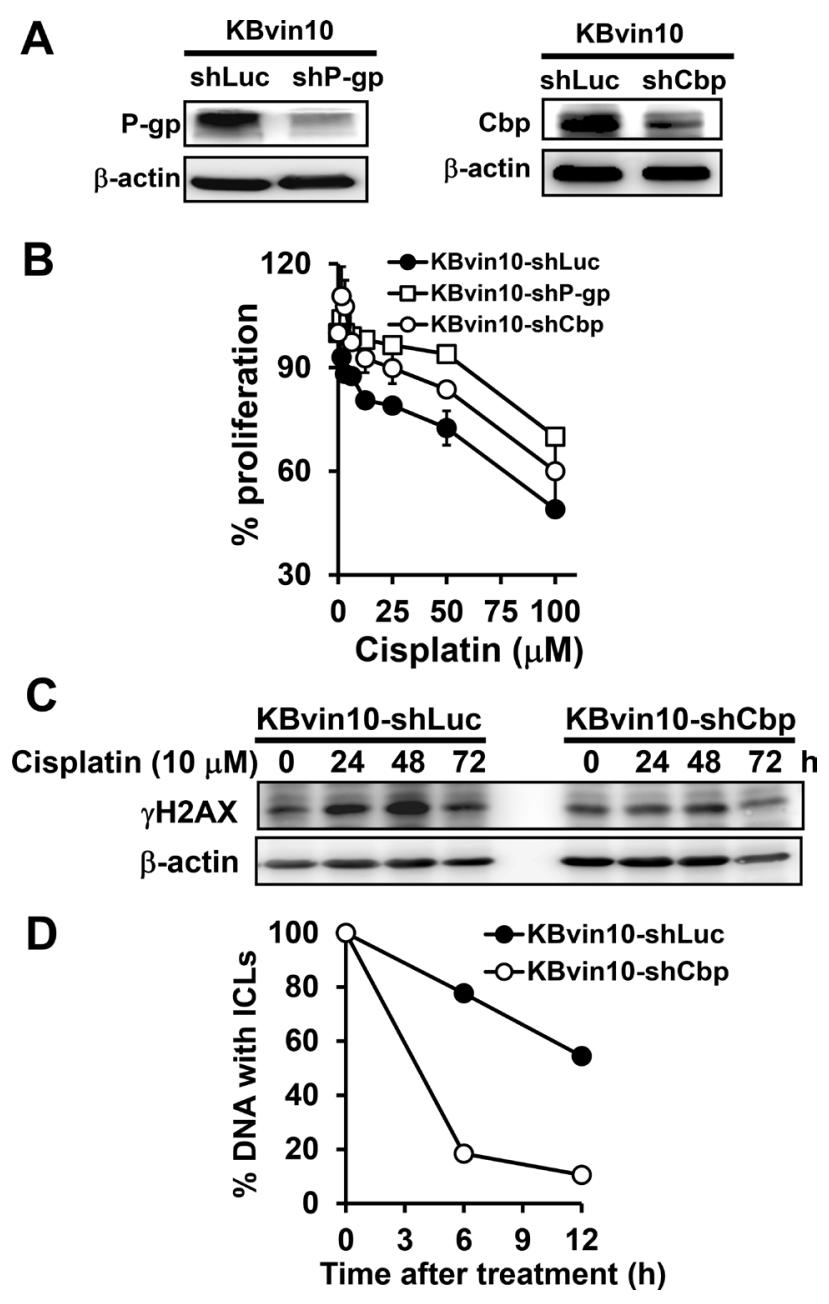

Figure 7: Increased resistance to DNA-damaging agents by P-gp or Cbp silencing. (A) Reduced P-gp or Cbp by shP-gp or shCbp, respectively. KBvin10 cells were infected with lentiviral shLuc, shP-gp, or shCbp for 24 h, washed, and cultured in medium containing $4 \mu \mathrm{g} / \mathrm{ml}$ puromycin. Four days after selection, P-gp and Cbp proteins in KBvin 10-shLuc, -shP-gp, or -shCbp cells were analyzed by western blotting. $\beta$-actin was included as a loading control. (B) Increased survival rate in P-gp-or Cbp-silenced cells treated with DNA-damaging agents. KBvin10-shLuc, -shP-gp, or -shCbp cells were treated with various concentrations of cisplatin for $1 \mathrm{~h}$, washed with PBS, and incubated for $72 \mathrm{~h}$. The cell proliferation was determined using Presto-Blue agents as described previously. Bars are SD of three independent experiments. (C) Decreased accumulation of gH2AX in cisplatin-treated KBvin10-shCbp cells. KBvin10-shLuc and -shCbp cells were treated with $10 \mu \mathrm{M}$ cisplatin for $1 \mathrm{~h}$, washed, and changed to drug-free medium for the indicated time. $\gamma \mathrm{H} 2 \mathrm{AX}$ levels were analyzed by western blotting. (D) Facilitating the repair of cisplatin-induced DNA ICLs in Cbp silencing cells. KBvin10-shLuc and KBvin10-shCbp cells were treated with $10 \mu \mathrm{M}$ cisplatin for $1 \mathrm{~h}$. Cisplatin-induced DNA ICLs were determined by a modified comet assay after incubation in drug-free medium for different time periods. Data are average of 2 independent experiments. 
Src and other Src family kinases are overexpressed and participate in numerous signaling pathways in various human cancers [49]. Activated Src has also been shown to cause cancer cells to be resistant to various chemotherapeutic agents and targeted therapeutics $[50,51]$. Actually, numerous reports have demonstrated that Src activation is involved in drug resistance by enhancing DNA repair [25-27]. Our present results showing that cisplatin treatment significantly increased the levels of $\mathrm{pSrc}^{\mathrm{Y} 416}$ (activated Src) as well as pEGFR ${ }^{\mathrm{Y} 845}$ in $\mathrm{KB}$ cells but not in P-gp overexpressed KBvin 10 cells. The phosphorylation of EGFR at Y845 was mediated by activated Src [43] and involved in regulation of DNArepair [26]. Furthermore, we found that overexpressed P-gp, either in acquired MDR cells or in ectopically expressed cells, interfered with cisplatin-induced phosphorylation of ATM, Chk2, Brca1 and Nbs1 that have been known as major regulators of DDR, which activate different DNA repair processes, including homologous recombination repair, non-homologous end joining repair [52]. These results supported that suppression of DNA-damaging agent-induced Src activation by P-gp is likely to inhibit DDR in MDR cells. This may be a reason to explain why MDR cells are more susceptible to cisplatin or other DNA ICL agents than the parental cells.

Uncovering the mechanisms of Src regulation and activation will probably provide new clues to guide cancer treatment $[29,53]$. In general, Src is activated via autophosphorylation of the tyrosine residue Y416 in its SH1 kinase domain and inactivated by phosphorylation of the negative regulator Y527 at its carboxy-terminal domain by Csk [49, 54]. Our current results revealed that the enhanced expression of P-gp reduces cisplatininduced active $\mathrm{pSrc}^{\mathrm{Y} 416}$ levels but significantly increases inactive $\mathrm{pSrc}^{\mathrm{Y} 527}$ levels, implying that $\mathrm{P}$-gp may increase the access of cytosolic Csk to membrane-anchored Src. However, overexpressed P-gp does not change Csk protein levels. Csk, existing in the cytoplasm for lacking a fatty acetylation site [55], must be recruited to the plasma membrane to exert its function. We further found that Cbp,

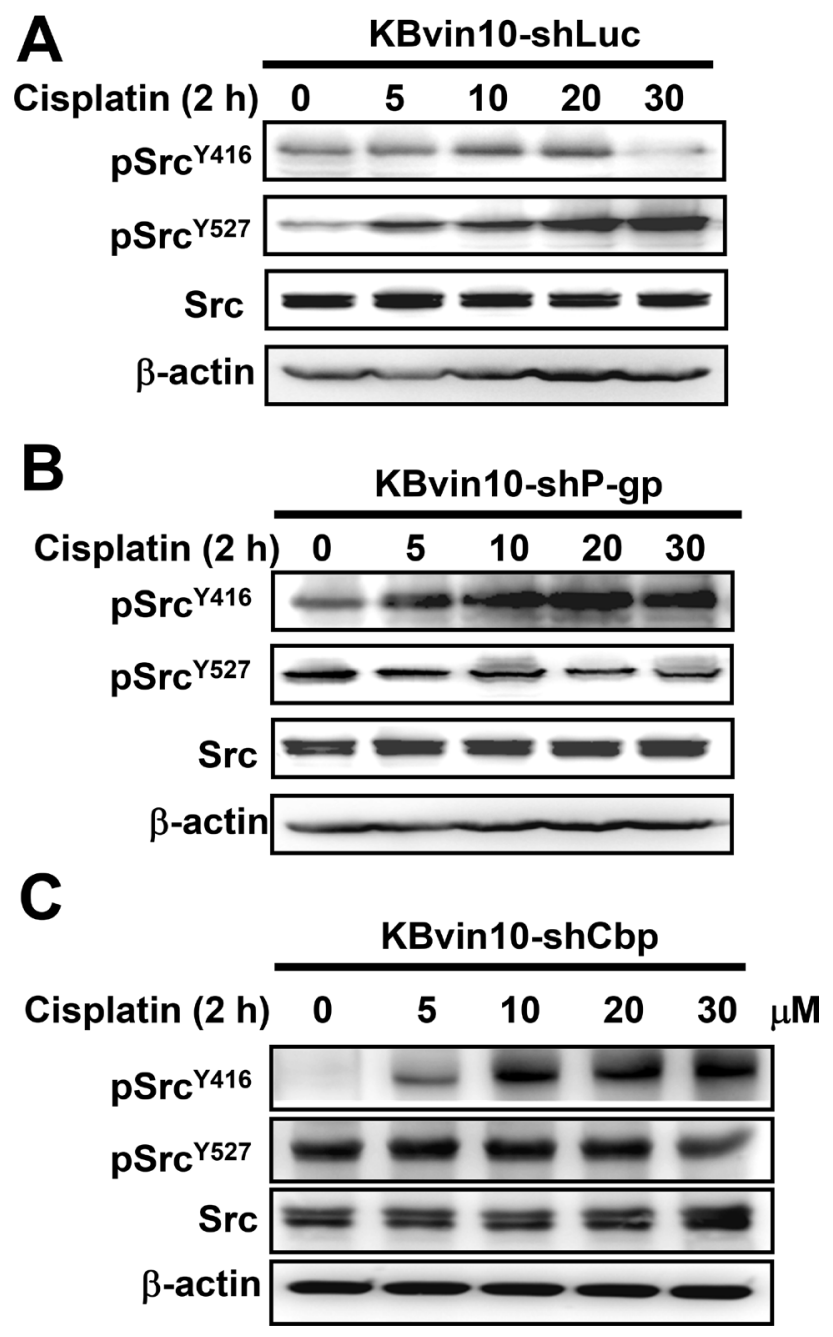

Figure 8: Enhanced Src activation in P-gp- or Cbp-silenced KBvin10 cells by cisplatin. KBvin10-shLuc (A), -shP-pg (B), and -shCbp (C) cells were treated with cisplatin at various concentrations for $1 \mathrm{~h}$, washed, and incubated with fresh medium for $2 \mathrm{~h}$. The levels of total $\mathrm{Src}, \mathrm{pSrc}^{\mathrm{Y} 416}$, and $\mathrm{pSrc}^{\mathrm{Y} 527}$ were determined by western blotting. $\beta$-actin was included as a loading control. 
a Csk binding protein that efficiently recruits cytosolic Csk to the plasma membrane was significantly increased in P-gp overexpressing cells. Therefore, we infer that overexpression of $\mathrm{P}$-gp and $\mathrm{Cbp}$ may facilitate recruitment of Csk to the membrane and result in phosphorylation of Src at Y527 upon treatment with DNA-damaging agents.

Src is mainly anchored to membranes via its N-terminal myristolyation and adaptor protein $[18,36]$. Numerous studies have shown that P-gp and Src are associated with lipid rafts $[40,56]$, where lipid raft modulation inhibits $\mathrm{P}$-gp and limits the transforming potential of Src $[57,58]$. Because we observed partial colocalization of P-gp, Cbp and Src on the plasma membrane, P-gp may upregulate Cbp to interfere with $\mathrm{Src}$ activation in cells treated with DNA-damaging agents. In addition to recruiting Csk to lipid raft-associated Src kinase, Cbp can also potentiate Csk enzymatic activity
[59]. Numerous reports have shown that the Cbp-Csk-Src pathway is involved in the regulation of Src signaling in response to diverse stimuli [60-62]. Our results indicated that Cbp was closely associated with P-gp overexpression in either acquired MDR cells, KBvin10, or ectopically expressed cells, Paca-S1-P1. We may further infer that $\mathrm{P}$-gp is involved in facilitating the negative regulatory Cbp-Csk-Src pathway, hence sensitizing MDR cells to certain DNA-damaging agents, such as cisplatin.

The mechanism of Cbp upregulation, particularly how P-gp enhances Cbp expression, remains elusive. $\mathrm{P}$-gp is a lipid translocase that induces the translocation of sphingomyelin and glucosylceramide across the plasma membrane [56]. Recent studies have shown that P-gp interferes with membrane lipid organization and facilitates the recruitment of Cbp [41]. Our present study demonstrated that enhanced $\mathrm{Cbp}$ in $\mathrm{P}$-gp overexpression
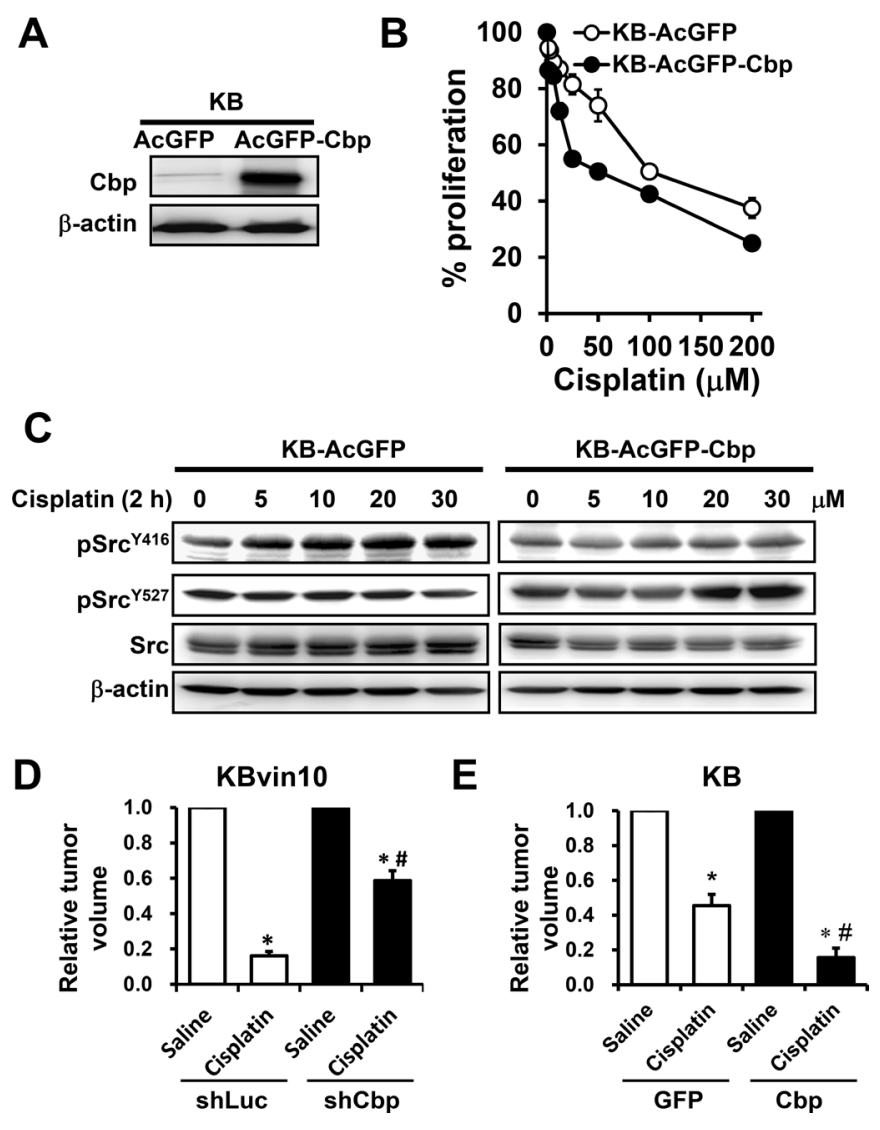

Figure 9: Attenuated Src activation by cisplatin in Cbp-overexpressing cells. (A) Enhanced Cbp expression in KB cells transfected with the Cbp expression vector. Stable cell lines were cloned and maintained in medium containing G418. The protein levels of $\mathrm{Cbp}$ in KB-AcGFP cells and KB-AcGFP-Cbp cells were analyzed by western blotting. (B) Increased sensitivity to DNA-damaging agents in Cbp-overexpressing cells. KB, KB-AcGFP and KB-AcGFP-Cbp cells were treated with cisplatin for $1 \mathrm{~h}$, washed and then incubated with fresh medium for $72 \mathrm{~h}$. The cell proliferation was determined using Presto-Blue. (C) Attenuation of Src activation by Cbp. KB-AcGFP and KB-AcGFP-Cbp cells were treated with cisplatin at various concentrations for $1 \mathrm{~h}$, washed, and incubated with fresh medium for $2 \mathrm{~h}$. The levels of total Src, $\mathrm{pSrc}^{\mathrm{Y} 416}$, and $\mathrm{pSrc}^{\mathrm{Y} 527}$ were determined by western blotting. $\beta$-actin was included as a loading control. (D and $\mathbf{E}$ ) Increased anti-tumor activity of cisplatin by enhanced Cbp expression. Athymic nude mice bearing cancer xenografts, derived from KBvin10-shLuc and KBvin10-shCbp cells (D) and from KB-GFP and KB-Cbp cells (E) were intratumorally treated with one dose of saline or cisplatin ( $4 \mathrm{mg} / \mathrm{kg}$ body weight) when the tumor reached a volume of $100 \mathrm{~mm}^{3}$ (6 mice/each group). Ten days after treatment, the tumor volumes were determined. Each bar represents the mean \pm S.E of 6 mice from 2 independent experiments. Statistical significance was determined by one-way ANOVAs. ${ }^{*} p<0.05$, saline vs. cisplatin; ${ }^{*} p<0.05$, KBvin10-shLuc $v s$ KBvin10-shCbp or KB-GFP $v s$ KB-Cbp cells treated with cisplatin. 
cells is likely because of increased transcription and protein stability. However, the interaction domains between P-gp and Cbp warrant further investigation.

Our study supports our previous finding that P-gp may play a special role in the inhibition of Src activation in cells exposed to DNA-damaging agents [16]. We further identified a critical role of $\mathrm{Cbp}$ in regulating P-gp-mediated Src activation and in sensitizing cancer cells to ICL agents. We also demonstrated that enhanced expression of $\mathrm{Cbp}$ could sensitize the xenografts to cisplatin in mice. These findings suggest that P-gp overexpressing cells might interfere with Cbp-CskSrc cascade and DDR and consequently enhance the sensitivity to DNA damaging agents, such as cisplatin or other DNA ICL agents. Therefore, DNA ICL agents might be potential therapeutic drugs against P-gp-overexpressing MDR cells, and Cbp mimics could serve as a potential agent for anticancer therapy.

\section{MATERIALS AND METHODS}

\section{Chemicals and reagents}

Vincristine, vinblastine, etoposide, paclitaxel (Taxol), cisplatin, carboplatin and melphalan were purchased from Sigma-Aldrich (St Louis, MO, USA), and doxorubicin from MP Biomedicals (Santa Ana, CA, USA). Cell culture chemicals were obtained from Gibco (Grand Island, NY, USA), and other reagents from Merck (Darmstadt, Germany). BO-1922 was synthesized according to our published procedure [42]. Cisplatin was freshly prepared by dissolving in dimethyl sulfoxide, immediately diluted with medium, and administrated into the culture dishes or wells.

\section{Cell lines and cell culture}

KB and KBvin10 cells, obtained from Dr. J. Y. Chang (National Health Research Institutes, Taiwan), were cultured as previously described [16]. KBvin10 cells overexpressing P-gp and vincristine resistance were derived from KB cells, which were originally thought to be an oral epidermal carcinoma cell line but with HeLa cell characteristics. Paca-S1 cells, derived from a pancreatic carcinoma Mia-Paca-2 xenograft by Dr. H. C. Wu (Institute of Cellular and Organismic Biology, Academia Sinica, Taiwan), were cultured in DMEM supplemented with $10 \%$ FBS and antibiotics.

\section{Cytotoxicity assay}

The cytotoxicity of various cell lines to various compounds was assessed using Presto Blue ${ }^{\circledR}$ (Life Technologies Co.) according to the manufacturer's instructions. Briefly, 3,000-5,000 cells were seeded in each well of 96 -well plates and incubated at $37^{\circ} \mathrm{C}$ overnight prior to drug treatment. In general, the cells were treated with various concentrations of drugs for $72 \mathrm{~h}$. At the end of treatment, an aliquot of Presto-Blue solution (at 1/10 volume) was added to each well, and the plates were further incubated at $37^{\circ} \mathrm{C}$ for $3 \mathrm{~h}$. Cell proliferation was assessed by determining the absorbance at $570 / 600 \mathrm{~nm}$ using a microplate spectrophotometer, and the $\mathrm{IC}_{50}$ values of each compound were calculated from the dose-effect relationships at six or seven concentrations using CompuSyn software (version 1.0.1; CompuSyn, Inc.) by Chou and Martin based on the median-effect principle and plot [63].

\section{Western blot analysis}

Western blotting was performed as previously described [64]. Equal amounts of cell lysates or immunoprecipitates were resolved by sodium dodecyl sulfate-polyacrylamide gel electrophoresis and subjected to western blotting using the following antibodies. Primary antibodies against P-gp, Csk and FANCD2 were obtained from Santa Cruz Biotechnology (Santa Cruz, CA, USA), Src, pSrc ${ }^{\mathrm{Y} 416}, \mathrm{pSrc}^{\mathrm{Y} 527}, \mathrm{ATM}^{\mathrm{pATM}}{ }^{\mathrm{S} 1981}, \mathrm{Chk}$, pChk2 ${ }^{\mathrm{T} 68}$, Brca1, pBrac1 ${ }^{\mathrm{S} 1524}$, Nbs1, pNbs1 ${ }^{\mathrm{S} 343}$, Mre11 and Rad50 from Cell Signaling Technology (Danvers, MA, USA), Rad51 from GeneTex (Irvine, CA, USA), $\gamma \mathrm{H} 2 \mathrm{AX}$ from Calbiochem (San Diego, CA, USA), and Cbp and $\beta$-actin from Abcam (Cambridge, MA, USA). The secondary horseradish peroxidase-conjugated antibody was purchased from Abcam (Cambridge, MA, USA). The specific protein bands were visualized by chemiluminescence using the SuperSignal West Pico chemiluminescence reagent (Pierce, Rockford, IL).

\section{Ectopic expression}

P-gp and Cbp were inserted into the pCMV6ENTRY and pCMV6-AC-GFP (OriGene Technologies, Rockville, MD, USA) expression vectors, respectively. The constructed plasmids were transfected into cells by Lipofectamine 2000 according to the manufacturer's instructions. Stable transfectants were selected by culturing the cells with $0.5 \mathrm{~g} / \mathrm{ml} \mathrm{G} 418$ (Gibco) for 2 weeks. Paca-S1 cells stably expressing P-gp were maintained in the presence of $10 \mathrm{nM}$ vincristine.

\section{Gene silencing by shRNA}

The lentiviruses containing the expression vectors of shRNAs of P-gp (pLKO.1-shP-gp) and Cbp (pLKO.1-shCbp) were obtained from the National RNAi Core Facility located at Academia Sinica, Taipei, Taiwan. The sequences of the P-gp and Cbp shRNAs were 5'-GCTCATCGTTTGTCTACAGTT-3' and 5'-TGATCTCTATGCTACTGTTAA-3', respectively. The lentiviral expression vector $\mathrm{pLKO} .1$-shLuc, containing 5'-GCGGTTGCCAAGAGGTTCCAT-3' specific for 
luciferase, was used as a vector control. To silence the expression of P-gp or Cbp, KBvin10 cells were infected with lentivirus containing the specific shRNA. These cell lines were maintained in the presence of $4 \mu \mathrm{g} / \mathrm{ml}$ puromycin.

\section{Reverse transcription polymerase chain reaction (PCR)}

Total RNA was extracted by using Trireagent (Sigma). The total RNAs were subjected to reverse transcription with SuperScript III (Invitrogen) for RNA synthesis. PCR was performed with the following pairs of specific primers: 5'-TCCGGTTTGGAGCCTACTTGG-3' and 5'-AGGCATGTATGTTGGCCTCC-3' for P-gp, 5'-TGGGGACATTCTTTCAGAGG-3' and 5'-GGTGGAC TCCGGAACTGTAA-3' for Cbp, 5'-CGAGATCCCTCC AAAATCAA-3' and 5'-TGCTGTAGCCAAATTCGTTG-3' for the glyceraldehyde-3-phosphate dehydrogenase gene (GAPDH). The PCR products were examined by electrophoresis on $2 \%$ agarose gels, stained with ethidium bromide, and visualized under UV light.

\section{Immunoprecipitation}

Cell were lysed in ice-cold lysis buffer $(50 \mathrm{mM}$ Tris- $\mathrm{HCl}$ at $\mathrm{pH} 7.5,150 \mathrm{mM} \mathrm{NaCl}, 1 \mathrm{mM}$ EDTA $\mathrm{pH}$ 8, $1 \%$ NP-40, and $0.25 \%$ deoxycholate containing a protease inhibitor cocktail set (Calbiochem) and $1 \mathrm{mM}$ each of phenylmethylsulfonyl fluoride and sodium orthovanadate) and pre-cleared by incubating with protein G-Sepharose beads for $30 \mathrm{~min}$. Pre-cleared lysates were incubated with the indicated primary antibody or isotype-specific IgG as a control overnight at $4^{\circ} \mathrm{C}$, followed by incubation with protein G-Sepharose beads (Millipore, Billerica, MA, USA) for $2 \mathrm{~h}$ at $4^{\circ} \mathrm{C}$. Immunocomplex beads were washed 3 times with PBS, immediately boiled in $2 \times$ sample buffer and then processed for electrophoresis and western blotting.

\section{Immunofluorescence staining}

To visualize the intracellular location of P-gp, Src or Cbp, KBvin 10 or Paca-S1 cells were cultured on slides, washed with cold PBS and fixed with $100 \%$ icecold methanol for $30 \mathrm{~min}$. Slides were then washed twice with PBS, permeabilized with PBS containing $0.2 \%$ Triton X-100 for $10 \mathrm{~min}$ and incubated overnight with appropriate antibody at $4^{\circ} \mathrm{C}$, followed by Alexa Fluor 488-conjugated secondary goat anti rabbit IgG antibodies or Alexa Fluor 555-conjugated secondary goat anti mouse IgG antibodies (Molecular Probes, Eugene, OR, USA). The nuclei were counterstained with 4',6-diamidino2-phenylindole (DAPI) as previously described [65]. After mounting with 50\% glycerol in PBS, images were acquired with a laser scanning confocal microscope (LSM 700, Carl Zeiss Microlmaging Inc., Thornwood, NY, USA) and AxioVision software.

\section{Modified comet assay}

The repair of intercellular DNA cross-linking in cells was analyzed using the modified comet assay as previously described [66]. Briefly, cells were treated with cisplatin for $1 \mathrm{~h}$ at $37^{\circ} \mathrm{C}$, followed by washing with PBS and incubating in fresh medium for $24 \mathrm{~h}$. At the end of the incubation, the cells were X-ray irradiated at a dose of 20 Gy and immediately subjected to single-cell alkaline gel electrophoresis. The percentage of ICLs in cells was estimated by the percentage decrease in the tail moment of cells irradiated with 20 Gy alone.

\section{Mouse xenografts}

Mouse xenografts were used to analyze the effects of cisplatin on the growth of cells expressing different levels of Cbp. The use of animals followed the guidelines approved by the Institutional Animal Care and Utilization Committee of the Academia Sinica (Taipei, Taiwan). Sixweek-old male BALB/c nude mice, obtained from the National Laboratory Animal Center (Taipei, Taiwan), were housed in a specific pathogen-free environment under controlled light and humidity conditions as previously described [67]. To generate the xenografts, aliquots of approximately $5 \times 10^{6} \mathrm{~KB}-\mathrm{GFP}$ or $\mathrm{KB}-\mathrm{Cbp}$ cells or $1 \times 10^{7} \mathrm{KBvin} 10$-shLuc or KBvin10-shCbp cells in $100 \mu \mathrm{l}$ of PBS were inoculated subcutaneously into the flank region. When the average tumor size reached approximately $100 \mathrm{~mm}^{3}$, the mice were randomly divided into two groups (3 for each group) and intratumorally injected once with vehicle (saline) or cisplatin (dissolved in saline and given at $4 \mathrm{mg} / \mathrm{kg}$ body weight). Tumor volumes $\left(\mathrm{mm}^{3}\right)$ were measured using calipers and calculated according to the formula: tumor volume $=\left(\right.$ length $\times$ width $\left.^{2}\right) / 2$.

\section{Abbreviations}

Multidrug resistance (MDR); ATP-binding cassette (ABC); P-glycoprotein (P-gp); interstrand cross-linking (ICL); DNA damage response (DDR); C-terminal Src kinase (Csk); Csk-binding protein (Cbp); phosphorylated histone $\mathrm{H} 2 \mathrm{AX} \quad(\gamma \mathrm{H} 2 \mathrm{AX})$; cycloheximide (CHX); polymerase chain reaction (PCR).

\section{Authors' contributions}

L.-F. L. and T.-C. L designed the study and wrote the paper. L.-F. L., I.-C. Ho, and V.K. P. performed the cellular and biochemical experiments. M.-H. W. conducted animal study and performed modified comet assay. T.-L. S. supplied the chemicals and discussion.

\section{ACKNOWLEDGMENTS}

We gratefully thank Dr. J. Y. Chang (National Health Research Institutes, Taiwan) and Dr. H. C. Wu (Institute 
of Cellular and Organismic Biology, Academia Sinica, Taiwan) for providing cell lines.

\section{CONFLICTS OF INTEREST}

The authors declare that there are no conflicts of interest.

\section{GRANT SUPPORT}

This work was supported by grants from the Academia Sinica (AS-100-TP-B13 to T.-L. Su and T.-C. Lee) and the Ministry of Science and Technology, Taiwan (NSC 100-2325-B-001-003, NSC 101-2325-B-001-002, and NSC 102-2325-B-001-002 to T.-L. Su and T.-C. Lee). L.-F. Lin was supported as Academia Sinica Postdoctoral Fellow by Academia Sinica.

\section{REFERENCES}

1. Szakacs G, Paterson JK, Ludwig JA, Booth-Genthe C, Gottesman MM. Targeting multidrug resistance in cancer. Nat Rev Drug Discov. 2006; 5:219-234.

2. Gottesman MM, Fojo T, Bates SE. Multidrug resistance in cancer: role of ATP-dependent transporters. Nat Rev Cancer. 2002; 2:48-58.

3. Fletcher JI, Haber M, Henderson MJ, Norris MD. ABC transporters in cancer: more than just drug efflux pumps. Nat Rev Cancer. 2010; 10:147-156.

4. Cole SP. Multidrug resistance protein 1 (MRP1, ABCC1), a "multitasking" ATP-binding cassette (ABC) transporter. J Biol Chem. 2014; 289:30880-30888.

5. Ford JM, Hait WN. Pharmacology of drugs that alter multidrug resistance in cancer. Pharmacol Rev. 1990; 42:155-199.

6. Roninson IB. The role of the MDR1 (P-glycoprotein) gene in multidrug resistance in vitro and in vivo. Biochem Pharmacol. 1992; 43:95-102.

7. Norgaard JM, Bukh A, Langkjer ST, Clausen N, Palshof T, Hokland P. MDR1 gene expression and drug resistance of AML cells. Br J Haematol. 1998; 100:534-540.

8. Chan HS, Grogan TM, Haddad G, DeBoer G, Ling V. P-glycoprotein expression: critical determinant in the response to osteosarcoma chemotherapy. J Natl Cancer Inst. 1997; 89:1706-1715.

9. Efferth T, Konkimalla VB, Wang YF, Sauerbrey A, Meinhardt S, Zintl F, Mattern J, Volm M. Prediction of broad spectrum resistance of tumors towards anticancer drugs. Clin Cancer Res. 2008; 14:2405-2412.

10. Takara K, Sakaeda T, Okumura K. An update on overcoming MDR1-mediated multidrug resistance in cancer chemotherapy. Curr Pharm Des. 2006; 12:273-286.

11. Turk D, Hall MD, Chu BF, Ludwig JA, Fales HM, Gottesman MM, Szakacs G. Identification of compounds selectively killing multidrug-resistant cancer cells. Cancer Res. 2009; 69:8293-8301.

12. Amiri-Kordestani L, Basseville A, Kurdziel K, Fojo AT, Bates SE. Targeting MDR in breast and lung cancer: discriminating its potential importance from the failure of drug resistance reversal studies. Drug Resist Updat. 2012; 15:50-61.

13. Pan GD, Yang JQ, Yan LN, Chu GP, Liu Q, Xiao Y, Yuan L. Reversal of multi-drug resistance by pSUPER-shRNAmdr1 in vivo and in vitro. World J Gastroenterol. 2009; $15: 431-440$.

14. Hall MD, Handley MD, Gottesman MM. Is resistance useless? Multidrug resistance and collateral sensitivity. Trends Pharmacol Sci. 2009; 30:546-556.

15. Jensen PB, Christensen IJ, Sehested M, Hansen HH, Vindelov L. Differential cytotoxicity of 19 anticancer agents in wild type and etoposide resistant small cell lung cancer cell lines. Br J Cancer. 1993; 67:311-320.

16. Lee PC, Lee HJ, Kakadiya R, Sanjiv K, Su TL, Lee TC. Multidrug-resistant cells overexpressing P-glycoprotein are susceptible to DNA crosslinking agents due to attenuated Src/nuclear EGFR cascade-activated DNA repair activity. Oncogene. 2013; 32:1144-1154.

17. Skorski T. Oncogenic tyrosine kinases and the DNAdamage response. Nat Rev Cancer. 2002; 2:351-360.

18. Brown MT, Cooper JA. Regulation, substrates and functions of src. Biochim Biophys Acta. 1996; 1287:121-149.

19. Frame MC. Newest findings on the oldest oncogene; how activated src does it. J Cell Sci. 2004; 117:989-998.

20. Sturge J, Caley MP, Waxman J. Bone metastasis in prostate cancer: emerging therapeutic strategies. Nat Rev Clin Oncol. 2011; 8:357-368.

21. Ischenko I, Camaj P, Seeliger H, Kleespies A, Guba M, De Toni EN, Schwarz B, Graeb C, Eichhorn ME, Jauch KW, Bruns CJ. Inhibition of Src tyrosine kinase reverts chemoresistance toward 5-fluorouracil in human pancreatic carcinoma cells: an involvement of epidermal growth factor receptor signaling. Oncogene. 2008; 27:7212-7222.

22. Yoshida T, Okamoto I, Okamoto W, Hatashita E, Yamada Y, Kuwata K, Nishio K, Fukuoka M, Janne PA, Nakagawa K. Effects of Src inhibitors on cell growth and epidermal growth factor receptor and MET signaling in gefitinibresistant non-small cell lung cancer cells with acquired MET amplification. Cancer Sci. 2010; 101:167-172.

23. Peterson-Roth E, Brdlik CM, Glazer PM. Src-Induced cisplatin resistance mediated by cell-to-cell communication. Cancer Res. 2009; 69:3619-3624.

24. Le XF, Bast RC Jr. Src family kinases and paclitaxel sensitivity. Cancer Biol Ther. 2011; 12:260-269.

25. Masumoto N, Nakano S, Fujishima H, Kohno K, Niho Y. $\mathrm{v}$-src induces cisplatin resistance by increasing the repair of cisplatin-DNA interstrand cross-links in human gallbladder adenocarcinoma cells. Int J Cancer. 1999; 80:731-737. 
26. Dittmann K, Mayer C, Kehlbach R, Rodemann HP. Radiation-induced caveolin-1 associated EGFR internalization is linked with nuclear EGFR transport and activation of DNA-PK. Mol Cancer. 2008; 7:69.

27. Dittmann K, Mayer C, Kehlbach R, Rothmund MC, Peter Rodemann H. Radiation-induced lipid peroxidation activates src kinase and triggers nuclear EGFR transport. Radiother Oncol. 2009; 92:379-382.

28. Chen G, Hitomi M. Dissociation of CDK2 from cyclin A in response to the topoisomerase II inhibitor etoposide in v-src-transformed but not normal NIH 3 T3 cells. Exp Cell Res. 1999; 249:327-336.

29. Mayer EL, Krop IE. Advances in targeting SRC in the treatment of breast cancer and other solid malignancies. Clin Cancer Res. 2010; 16:3526-3532.

30. Xu W, Harrison SC, Eck MJ. Three-dimensional structure of the tyrosine kinase c-Src. Nature. 1997; 385:595-602.

31. Okada M. Regulation of the SRC family kinases by Csk. Int J Biol Sci. 2012; 8:1385-1397.

32. Howell BW, Cooper JA. Csk suppression of Src involves movement of Csk to sites of Src activity. Mol Cell Biol. 1994; 14:5402-5411.

33. Sabe H, Hata A, Okada M, Nakagawa H, Hanafusa $H$. Analysis of the binding of the Src homology 2 domain of Csk to tyrosine-phosphorylated proteins in the suppression and mitotic activation of c-Src. Proc Natl Acad Sci U S A. 1994; 91:3984-3988.

34. Cao H, Courchesne WE, Mastick CC. A phosphotyrosinedependent protein interaction screen reveals a role for phosphorylation of caveolin-1 on tyrosine 14: recruitment of C-terminal Src kinase. J Biol Chem. 2002; 277:8771-8774.

35. Hur EM, Son M, Lee OH, Choi YB, Park C, Lee H, Yun Y. LIME, a novel transmembrane adaptor protein, associates with p561ck and mediates $\mathrm{T}$ cell activation. J Exp Med. 2003; 198:1463-1473.

36. Kawabuchi M, Satomi Y, Takao T, Shimonishi Y, Nada S, Nagai K, Tarakhovsky A, Okada M. Transmembrane phosphoprotein Cbp regulates the activities of Src-family tyrosine kinases. Nature. 2000; 404:999-1003.

37. Brdicka T, Pavlistova D, Leo A, Bruyns E, Korinek V, Angelisova P, Scherer J, Shevchenko A, Hilgert I, Cerny J, Drbal K, Kuramitsu Y, Kornacker B, et al. Phosphoprotein associated with glycosphingolipid-enriched microdomains (PAG), a novel ubiquitously expressed transmembrane adaptor protein, binds the protein tyrosine kinase csk and is involved in regulation of T cell activation. J Exp Med. 2000; 191:1591-1604.

38. Shima T, Nada S, Okada M. Transmembrane phosphoprotein Cbp senses cell adhesion signaling mediated by Src family kinase in lipid rafts. Proc Natl Acad Sci USA. 2003; 100:14897-14902.

39. Rotty JD, Coulombe PA. A wound-induced keratin inhibits Src activity during keratinocyte migration and tissue repair. J Cell Biol. 2012; 197:381-389.
40. Oneyama C, Hikita T, Enya K, Dobenecker MW, Saito K, Nada S, Tarakhovsky A, Okada M. The lipid raft-anchored adaptor protein $\mathrm{Cbp}$ controls the oncogenic potential of c-Src. Mol Cell. 2008; 30:426-436.

41. Hammadi M, Youinou P, Tempescul A, Tobon G, Berthou C, Bordron A, Pers JO. Membrane microdomain sphingolipids are required for anti-CD20-induced death of chronic lymphocytic leukemia B cells. Haematologica. 2012; 97:288-296.

42. Chaniyara R, Tala S, Chen CW, Zang X, Kakadiya R, Lin LF, Chen CH, Chien SI, Chou TC, Tsai TH, Lee TC, Shah A, Su TL. Novel antitumor indolizino[6,7-b]indoles with multiple modes of action: DNA cross-linking and topoisomerase I, II inhibition. J Med Chem. 2013; 56: 1544-1563.

43. Sato K, Sato A, Aoto M, Fukami Y. c-Src phosphorylates epidermal growth factor receptor on tyrosine 845 . Biochem Biophys Res Commun. 1995; 215:1078-1087.

44. Yague E, Armesilla AL, Harrison G, Elliott J, Sardini A, Higgins CF, Raguz S. P-glycoprotein (MDR1) expression in leukemic cells is regulated at two distinct steps, mRNA stabilization and translational initiation. J Biol Chem. 2003; 278:10344-10352.

45. Place AT, Chen Z, Bakhshi FR, Liu G, O'Bryan JP, Minshall RD. Cooperative role of caveolin-1 and C-terminal Src kinase binding protein in C-terminal Src kinasemediated negative regulation of c-Src. Mol Pharmacol. 2011; 80:665-672.

46. Bergman AM, Pinedo HM, Talianidis I, Veerman G, Loves WJ, van der Wilt CL, Peters GJ. Increased sensitivity to gemcitabine of P-glycoprotein and multidrug resistanceassociated protein-overexpressing human cancer cell lines. Br J Cancer. 2003; 88:1963-1970.

47. Szakacs G, Annereau JP, Lababidi S, Shankavaram U, Arciello A, Bussey KJ, Reinhold W, Guo Y, Kruh GD, Reimers M, Weinstein JN, Gottesman MM. Predicting drug sensitivity and resistance: profiling $\mathrm{ABC}$ transporter genes in cancer cells. Cancer Cell. 2004; 6:129-137.

48. Pluchino KM, Hall MD, Goldsborough AS, Callaghan R, Gottesman MM. Collateral sensitivity as a strategy against cancer multidrug resistance. Drug Resist Updat. 2012; 15:98-105.

49. Yeatman TJ. A renaissance for SRC. Nat Rev Cancer. 2004; 4:470-480.

50. Ceppi P, Papotti M, Monica V, Lo Iacono M, Saviozzi S, Pautasso M, Novello S, Mussino S, Bracco E, Volante M, Scagliotti GV. Effects of Src kinase inhibition induced by dasatinib in non-small cell lung cancer cell lines treated with cisplatin. Mol Cancer Ther. 2009; 8:3066-3074.

51. Zhang S, Huang WC, Li P, Guo H, Poh SB, Brady SW, Xiong Y, Tseng LM, Li SH, Ding Z, Sahin AA, Esteva FJ, Hortobagyi GN, et al. Combating trastuzumab resistance by targeting SRC, a common node downstream of multiple resistance pathways. Nat Med. 2011; 17:461-469. 
52. Panier S, Durocher D. Push back to respond better: regulatory inhibition of the DNA double-strand break response. Nat Rev Mol Cell Biol. 2013; 14:661-672.

53. Creedon H, Brunton VG. Src kinase inhibitors: promising cancer therapeutics? Crit Rev Oncog. 2012; 17:145-159.

54. Martin GS. The hunting of the Src. Nat Rev Mol Cell Biol. $2001 ; 2: 467-475$.

55. Nada S, Yagi $T$, Takeda $H$, Tokunaga $T$, Nakagawa $H$, Ikawa Y, Okada M, Aizawa S. Constitutive activation of Src family kinases in mouse embryos that lack Csk. Cell. 1993; 73:1125-1135.

56. Orlowski S, Martin S, Escargueil A. P-glycoprotein and 'lipid rafts': some ambiguous mutual relationships (floating on them, building them or meeting them by chance?). Cell Mol Life Sci. 2006; 63:1038-1059.

57. Oneyama C, Iino T, Saito K, Suzuki K, Ogawa A, Okada M. Transforming potential of Src family kinases is limited by the cholesterol-enriched membrane microdomain. Mol Cell Biol. 2009; 29:6462-6472.

58. Yun UJ, Lee JH, Koo KH, Ye SK, Kim SY, Lee CH, Kim YN. Lipid raft modulation by Rp1 reverses multidrug resistance via inactivating MDR-1 and Src inhibition. Biochem Pharmacol. 2013; 85:1441-1453.

59. Takeuchi S, Takayama Y, Ogawa A, Tamura K, Okada M. Transmembrane phosphoprotein Cbp positively regulates the activity of the carboxyl-terminal Src kinase, Csk. J Biol Chem. 2000; 275:29183-29186.

60. Matsuoka H, Nada S, Okada M. Mechanism of Cskmediated down-regulation of Src family tyrosine kinases in epidermal growth factor signaling. J Biol Chem. 2004; 279:5975-5983.
61. Rey-Barroso J, Colo GP, Alvarez-Barrientos A, RedondoMunoz J, Carvajal-Gonzalez JM, Mulero-Navarro S, Garcia-Pardo A, Teixido J, Fernandez-Salguero PM. The dioxin receptor controls beta1 integrin activation in fibroblasts through a Cbp-Csk-Src pathway. Cell Signal. 2013; 25:848-859.

62. Zhang SQ, Yang W, Kontaridis MI, Bivona TG, Wen G, Araki T, Luo J, Thompson JA, Schraven BL, Philips MR, Neel BG. Shp2 regulates SRC family kinase activity and Ras/Erk activation by controlling Csk recruitment. Mol Cell. 2004; 13:341-355.

63. Chou TC. Theoretical basis, experimental design, and computerized simulation of synergism and antagonism in drug combination studies. Pharmacol Rev. 2006; 58:621-681.

64. Lai KC, Chang KW, Liu CJ, Kao SY, Lee TC. IFN-induced protein with tetratricopeptide repeats 2 inhibits migration activity and increases survival of oral squamous cell carcinoma. Mol Cancer Res. 2008; 6:1431-1439.

65. Chen YJ, Lai KC, Kuo HH, Chow LP, Yih LH, Lee TC. HSP70 colocalizes with PLK1 at the centrosome and disturbs spindle dynamics in cells arrested in mitosis by arsenic trioxide. Arch Toxicol. 2014; 88:1711-1723.

66. Kakadiya R, Dong H, Lee PC, Kapuriya N, Zhang X, Chou TC, Lee TC, Kapuriya K, Shah A, Su TL. Potent antitumor bifunctional DNA alkylating agents, synthesis and biological activities of 3a-aza-cyclopenta[a]indenes. Bioorg Med Chem. 2009; 17:5614-5626.

67. Sanjiv K, Su TL, Suman S, Kakadiya R, Lai TC, Wang HY, Hsiao M, Lee TC. The novel DNA alkylating agent BO1090 suppresses the growth of human oral cavity cancer in xenografted and orthotopic mouse models. Int J Cancer. 2012; 130:1440-1450. 